\title{
TESTANDO OS DOZE EQUÍVOCOS SOBRE AS MIGRAÇÕES DE GRIMSON: O CASO DO BRASIL NO INÍCIO DO SÉCULO XXI
}

\author{
TESTING THE GRIMSON'S TWELVE MISTAKES ON MIGRATIONS: \\ THE CASE OF BRAZIL IN THE BEGINNING OF THE $21^{\text {ST }}$ CENTURY
}

\section{TESTANDO LOS DOCE EQUÍVOCOS SOBRE LAS MIGRACIONES DE GRIMSON: EL CASO DE BRASIL EN EL INICIO DEL SIGLO VEINTIUNO}

\section{Roberto Rodolfo Georg Uebel}

Doutorando do Programa de Pós-graduação em Estudos Estratégicos Internacionais da Universidade Federal do Rio Grande do Sul (UFRGS). Faculdade de Ciências Econômicas - Universidade Federal do Rio Grande do Sul

Av. João Pessoa, 52 - sala 33A - $3^{\circ}$ andar. CEP 90040-000 - Centro - Porto Alegre/RS - Brasil

E.mail: roberto.uebel@ufrgs.br

\section{RESUMO}

O geoantropólogo argentino Alejandro Grimson em seu recente aclamado artigo "Doce equívocos sobre las migraciones" (2011) provoca a uma reflexão sobre doze paradigmas falaciosos - ou equívocos - acerca das migrações internacionais contemporâneas, dentre estes, muitos difundidos pela mídia e pelo discurso comum. Nesse sentido, considerando-se que o Brasil passou por dois booms imigratórios no início do século XXI (no ano 2010 e no biênio 2013-2014), com um estoque migratório de quase dois milhões de imigrantes em 2015, o artigo confronta estas doze proposições com o cenário contemporâneo brasileiro, discutindo-se suas efetividades, realidades e problemáticas, com base nos dados estatísticos, bibliográficos e populacionais disponíveis, além dos aportes da Geografia Política e Geoeconomia, procurando, por fim, fazer uma ligação e breve análise de cada item à realidade brasileira.

Palavras-chave: Migrações. Brasil. Grimson. Equívocos. Século XXI.

\section{ABSTRACT}

The Argentinean geoanthropologist Alejandro Grimson in his recent and acclaimed article "Doce equívocos sobre las migraciones" (2011) induces a reflection on twelve fallacious paradigms - or mistakes - about the contemporary international migration, among them, many disseminated by the media and the common discourse. In this sense, considering that Brazil has experienced two immigration booms in the beginning of the $21^{\text {st }}$ century (in 2010 and in the biennium 2013-2014), with a migratory stock of nearly two million immigrants in 2015, the article confronts these twelve propositions with the Brazilian contemporary scenario, discussing their effectiveness, realities and issues, based on the statistical, bibliographic and population data available, in addition to the 
contributions of Political Geography and Geoeconomics, looking for, finally, making a connection and brief analysis of each item to the Brazilian reality.

Keywords: Migrations. Brazil. Grimson. Mistakes. $21^{\text {st }}$ century.

\section{RESUMEN}

Elgeoantropólogo argentino Alejandro Grimson en su reciente y aclamado artículo “Doce equívocos sobre las migraciones" provoca una reflexión sobre doce paradigmas falaces o equívocos - acerca de las migraciones internacionales contemporáneas, entre estos, muchos difundidos por la prensa y discurso común. En esta dirección, considerándose que Brasil ha experimentado dos booms inmigratorios en el inicio del siglo veintiuno (en 2010 y en el bienio 2013-2014), con un número de inmigrantes próximo a dos millones de individuos en 2015, este artículo confronta estos doces proposiciones con el escenario contemporáneo brasileño, discutiendo sus efectividades, realidades y problemáticas, con base en los datos estadísticos, bibliográficos y poblacionales disponibles, además de los aportes de la Geografía Política y Geoeconomía, procurando, por fin, hacer un enlace y un breve análisis de cada elemento a la realidad brasileña.

Palabras-clave: Migraciones. Brasil. Grimson. Equívocos. Siglo veintiuno.

\section{INTRODUÇÃO}

As migrações internacionais para o Brasil vêm ganhando singular destaque desde que Bacha e Klein (1989) apontaram o ano de 1985 como divisor de águas nas relações do Brasil com as escalas globais (articuladas em rede) em diversas questões setoriais, como desde o início da abertura à democracia no país como a nova caracterização do território brasileiro para o recebimento de imigrantes estrangeiros.

As razões que levaram a este deslocamento de pessoas em crescimento verificado ao longo das últimas três décadas foram motivadas especialmente pela própria transformação das relações e escalas a nível internacional, tendo-se, por exemplo, questões de conflitos étnicos e civis, desastres naturais, nestes dois casos como colocam Barnett e Adger (2007), além de condições econômicas e laborais como repercussões e "fomentadoras" de tal processo migratório em uma escala global, que se relacionam em uma escala nacional com questões do uso do espaço brasileiro (tanto de corte social como territorial-geográfico), fronteiras e política setorial de imigração com repercussões territoriais e, diretamente, nas escalas regionais com questões de trabalho, assistência social e outras temáticas pertinentes à imigração.

Estas escalas e redes relacionam-se dentro deste cenário, mais recentemente descrito pela obra Perfil Migratório do Brasil 2009, de autoria do Ministério do Trabalho e Emprego 
do Brasil com a Organização Internacional para as Migrações (ORGANIZAÇÃO INTERNACIONAL PARA AS MIGRAÇÕES, 2009), que em relação com o referencial teórico e literatura recente sobre o tema, fornecem-nos lacunas a serem estudadas para respondermos questões importantes sobre este novo e contemporâneo panorama (cenário) das imigrações para o Brasil e seu perfil socioespacial, considerando principalmente os apontamentos da Geopolítica e Geoeconomia à luz das migrações internacionais.

Ademais, neste diapasão conceitual e referencial teórico, Grimson (2011) provocanos em seu recente artigo a uma reflexão sobre doze paradigmas falaciosos acerca das migrações internacionais contemporâneas, a saber: 1) Confundir migrações com migrações internacionais; 2) Confundir migrações internacionais com migrações Sul-Norte; 3 ) Supor que estamos na era das migrações; 4) Supor que "muita gente" implica "problemas maiores"; 5) Confundir migrações com pobreza; 6) Crer que as pessoas "se movimentam com suas culturas"; 7) Identificar migração com diáspora; 8) Crer que existem imigrantes de segunda geração; 9) Crer que maior tempo de residência implica maior integração social; 10) A confusão entre transnacionalismo e translocalismo; 11) Crer que toda situação migratória representa um "encontro entre duas culturas"; 12) Assumir o discurso que apenas os nativos possuem direitos.

Nesse sentido, considerando-se que o Brasil passou por dois booms imigratórios no início do século XXI (no ano 2010 e no biênio 2013-2014), que apresentou até o primeiro semestre de 2014 um estoque ${ }^{1}$ de quase dois milhões de imigrantes. ${ }^{2}$, pretende-se confrontar estas doze proposições com o cenário contemporâneo brasileiro, discutindo-se suas efetividades, realidades e problemáticas, com base nos dados estatísticos, bibliográficos e populacionais disponíveis, além dos aportes da Geografia Política e Geoeconomia, procurando, por fim, fazer uma ligação e breve análise de cada item à realidade brasileira.

\section{CONFUNDIR MIGRAÇÕES COM MIGRAÇÕES INTERNACIONAIS}

Grimson (2011) propõe no seu primeiro paradigma que há uma amalgamação interpretativa entre o que se considera "migrações" e "migrantes" e "migrações internacionais" e "imigrantes" no trato dos Estados nacionais, principalmente quando da abordagem pela mídia.

Ademais, aponta que o mesmo se verifica no caso dos refugiados e asilados, ainda que de forma mais parametrizada:

Por "estoque imigratório" compreende-se o número total de imigrantes no território em análise, em dado período de tempo, isto é, um saldo imigratório ou grosso modo o número total de indivíduos imigrantes.

2 Estes dados foram obtidos por meio da Lei de Acesso à Informação. Todos os dados foram tabulados e compilados pelos autores, encontrando-se disponíveis nesta página: https://www.dropbox.com/sh/fg7dq7xq6gj2049/AACobhS-eurv0vpTHSeBfiIta?dl=0. 
"[...] la categoría de «refugiado» ha tendido a reservarse para casos internacionales, pero hay fenómenos de desplazamiento territorial masivo, como por ejemplo los provocados por la guerra en Colombia, que involucran a millones de personas dentro de un Estado-nación." (GRIMSON, 2011, p. 35)

Em relação ao cenário brasileiro, o que se verificou é o mélange interpretativo sobre os imigrantes econômicos haitianos e senegaleses, em especial após o boom de 2010, onde setores da imprensa insistem em caracterizar estes migrantes internacionais como refugiados, conforme o extrato do Jornal Zero Hora:

[Título] Porto Alegre se prepara para receber refugiados haitianos. [Subtítulo]: Imigrantes serão encaminhados para o Centro Vida Humanístico, na zona norte. Seis meses depois, a novela se repete: sem aviso prévio, o governo do Acre envia haitianos para o território gaúcho. Desde quinta-feira, a prefeitura de Porto Alegre corre contra o tempo para se preparar para receber os refugiados do país devastado pela pobreza. (PEREIRA, 2015)

Percebe-se em recorrentes publicações impressas da mídia, bem como nos noticiários e portais de notícias, um desconhecimento e desinformação generalizada dos veículos de imprensa quanto aos fatos e fluxos noticiados, posto que é consenso tanto na academia como por parte dos órgãos governamentais, em especial o Comitê Nacional para Refugiados (CONARE) e Conselho Nacional de Imigração (CNIg), de que os haitianos e senegaleses, em especial, são imigrantes econômicos, e não refugiados, apesar de que as condições nos seus países de origem sejam caracterizadas pela escassez de recursos e instabilidade social, majoritariamente, não sofrem perseguições políticas, como no caso dos refugiados sírios, sendo esta a condição primaz para a caracterização e obtenção do status de refugiado.

\section{CONFUNDIR MIGRAÇÕES INTERNACIONAIS COM MIGRAÇÕES SUL-NORTE}

Já no seu segundo paradigma, Grimson (2011) aponta que há uma confusão conceitual e interpretativa entre migrações internacionais com migrações Sul-Norte, como prossegue:

Desde los países centrales existe la tendencia a observar y analizar las migraciones internacionales como un fenómeno poblacional relacionado con el arribo a esos mismos países, dejando en un plano secundario las dinámicas regionales que se producen en el Cono Sur, en Centroamérica (Nicaragua/Costa Rica) y en diferentes zonas de Asia y África. Las migraciones hacia Europa desde las ex-colonias son un fenómeno tan peculiar como cualquier otro. Aproximadamente uno de cada tres migrantes actuales se desplaza entre regiones y países “del Sur”.(GRIMSON, 2011, p. 35)

Analisando-se o ranking dos 20 maiores grupos imigratórios no Brasil na periodização feita por Uebel (2015) que vai do ano 2000 até outubro de 2014, comprova-se, com a Figura 1 com o quadro abaixo, o primeiro equívoco apontado por Grimson (2011): 
Figura 1 - Quadro/Ranking dos grupos migratórios no Brasil por nacionalidade - 2000; 2007-2014.

\begin{tabular}{|c|c|c|c|c|c|c|c|c|c|c|c|}
\hline Nacionalidade/Ano & 2000 & 2007 & 2008 & 2009 & 2010 & 2011 & 2012 & 2013 & 2014 & Total p/ Nacionalidade & Ranking \\
\hline Portugal & 4.290 & 551 & 692 & 719 & 30.577 & 1.599 & 2.247 & 3.021 & 279.772 & 323.468 & 10 \\
\hline Estados Unidos & 7.628 & 4.505 & 6.332 & 6.318 & 72.265 & 10.172 & 9.209 & 9.004 & 38.149 & 163.582 & 20 \\
\hline Japão & 5.364 & 1.251 & 1.843 & 1.307 & 49.261 & 2.276 & 2.323 & 2.029 & 91.736 & 157.390 & 30 \\
\hline Bolívia & 6.489 & 104 & 170 & 118 & 26.002 & 79 & 83 & 45 & 79.738 & 112.828 & 40 \\
\hline Itália & 3.584 & 1.387 & 1.469 & 1.579 & 19.095 & 2.478 & 3.065 & 2.774 & 76.538 & 111.969 & 50 \\
\hline Espanha & 2.124 & 901 & 1.272 & 1.215 & 20.212 & 1.897 & 2.059 & 2.752 & 64.974 & 97.406 & 60 \\
\hline Argentina & 8.483 & 633 & 676 & 622 & 15.291 & 538 & 489 & 486 & 53.138 & 80.356 & 70 \\
\hline China & 2.908 & 1.091 & 2.821 & 1.750 & 9.208 & 2.643 & 3.104 & 2.363 & 42.302 & 68.190 & 80 \\
\hline Paraguai & 11.156 & 32 & 40 & 47 & 32.139 & 15 & 23 & 14 & 24.402 & 67.868 & go \\
\hline Alemanha & 2.832 & 1.294 & 1.925 & 1.569 & 11.321 & 3.181 & 3.617 & 2.932 & 33.143 & 61.814 & 100 \\
\hline Reino Unido & 1.867 & 2.812 & 4.457 & 4.141 & 21.045 & 4.954 & 4.414 & 4.150 & 13.901 & 61.741 & 110 \\
\hline França & 3.079 & 1.380 & 1.643 & 2.057 & 11.994 & 2.305 & 2.530 & 2.489 & 23.595 & 51.072 & 120 \\
\hline Uruguai & 5.431 & 36 & 52 & 59 & 8.514 & 63 & 34 & 59 & 35.744 & 49.992 & 130 \\
\hline Filipinas & 79 & 2.191 & 4.909 & 5.266 & 6.711 & 7.793 & 5.179 & 5.122 & 7.257 & 44.507 & $14^{\circ}$ \\
\hline Peru & 3.655 & 311 & 576 & 526 & 7.915 & 659 & 639 & 512 & 25.009 & 39.802 & 150 \\
\hline Chile & 1.997 & 245 & 326 & 345 & 4.829 & 302 & 311 & 298 & 28.672 & 37.325 & $16^{\circ}$ \\
\hline Coreia do Sul & 1.546 & 126 & 197 & 208 & 3.601 & 1.440 & 2.318 & 1.464 & 21.692 & 32.592 & 170 \\
\hline Colômbia & 1.812 & 417 & 935 & 940 & 5.758 & 1.028 & 1.035 & 662 & 19.833 & 32.420 & $18^{\circ}$ \\
\hline Haiti & 0 & 1 & 14 & 6 & 175 & 720 & 4.860 & 2.086 & 20.108 & 27.970 & 190 \\
\hline Índia & 232 & 1.286 & 2.001 & 2.631 & 3.610 & 4.261 & 4.243 & 3.757 & 4.960 & 26.981 & $200^{\circ}$ \\
\hline
\end{tabular}

Fonte: Dados do IBGE, MTE, Polícia Federal compilados pelo autor.

Destes 20 maiores grupos imigratórios, seis são de origem do continente europeu (portugueses, italianos, espanhóis, alemães, britânicos e franceses), um da América do Norte (estadunidenses), cinco da Ásia (japoneses, chineses, filipinos, sul-coreanos e indianos), um do Caribe (haitianos) e sete da América Latina (bolivianos, argentinos, paraguaios, uruguaios, peruanos, chilenos e colombianos). Portanto, 12 nacionalidades são de origem do "Norte Geográfico" do planeta e apenas 8 do Sul. Caso fosse considerada a acepção de Norte e Sul econômicos, a proporção seria ainda de dominância numérica nos fluxos do Norte em direção ao Brasil.

O mapa da Figura 2 traduz a origem destes imigrantes dadas as suas nacionalidades e comprova que a distribuição numérica se equipara, além de uma falaciosa comparação entre originários do Norte e do Sul, como denuncia Grimson (2011): 
Figura 2 - Estoque de imigrantes no Brasil de acordo com a sua nacionalidade - 2007/2014.

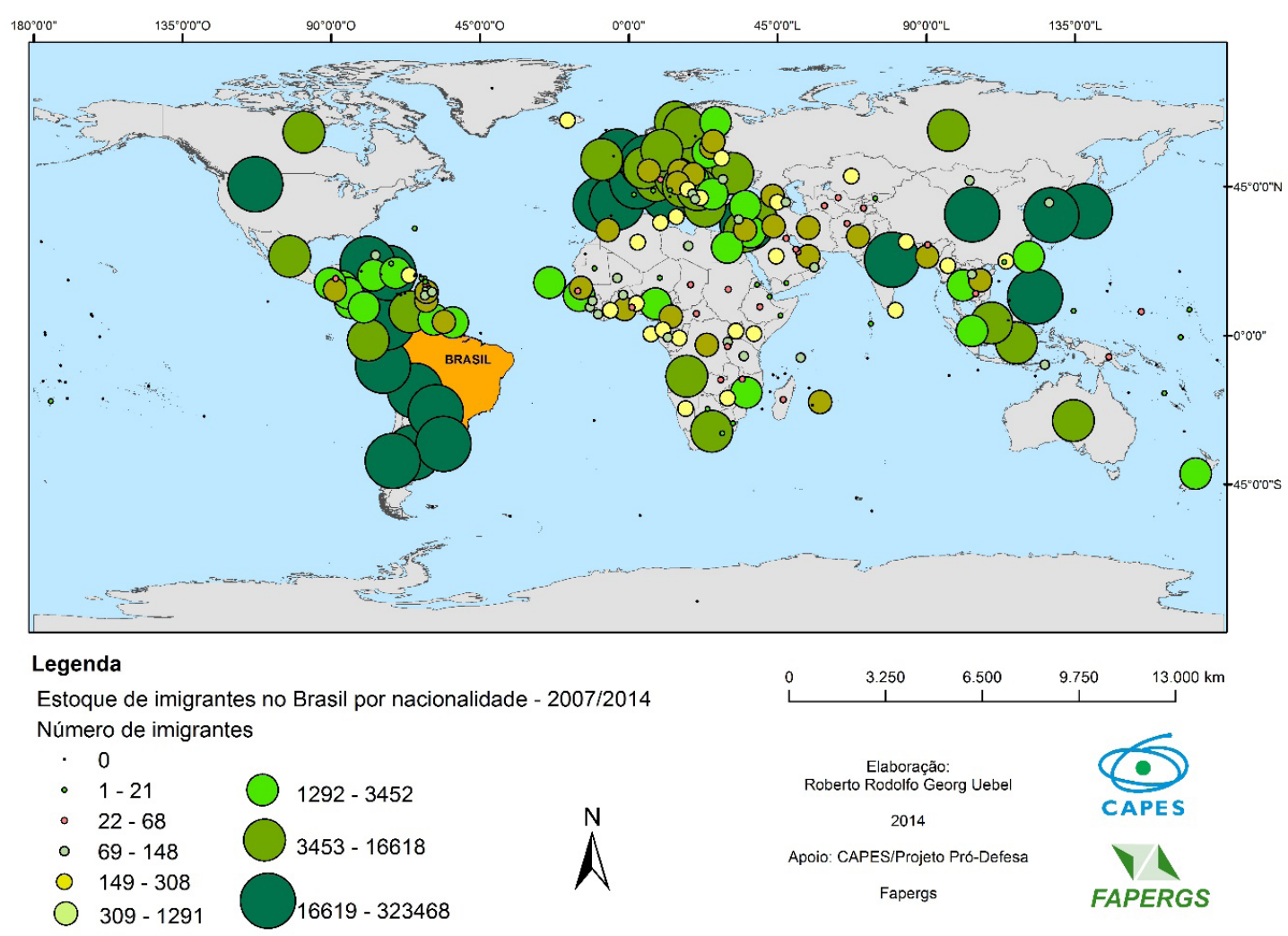

Elaborado pelo autor.

Essas vinte maiores diferenças apontam para uma mudança na própria multipolarização econômica e estrutural que já apontava no início da década passada uma projeção maior da inserção do Brasil na agenda internacional, atraindo imigrantes para cargos especializados com forte exigência de mão de obra qualificada, que durante o decênio não apresentou crescimento considerável interno no Brasil para suprir estas carências, o que justifica o expressivo aumento do número de imigrantes portugueses, japoneses, italianos, estadunidenses, britânicos, alemães e de outras nacionalidades reconhecidamente formadoras de mão de obra qualificada e que sofreram com a crise econômica no período analisado, gerando desemprego em seus países.

Estes países, notoriamente conhecidos por sua mão de obra altamente qualificada e por serem base de grandes centros de tecnologia e inovação, acabam participando de um fenômeno de mass migration explicado por Hatton e Williamson (1998), que exporta o excesso de profissionais para países em ascensão na agenda internacional de comércio, indústria e investimento em serviços, o caso do Brasil. Portanto, não surpreende que justamente estas nações sejam apontadas como aquelas que mais cresceram no ranking 
de envio de imigrantes ao território brasileiro.

Logo, sob o ponto de vista do perfil imigratório brasileiro, não se pode falar que exista uma predominância de migrações do tipo Sul-Sul ou Oeste-Leste, mas sim de um fenômeno geral de migrações internacionais, com representações e fluxos consideráveis de vários continentes e nações, estando estas localizadas no Norte ou no Sul.

\section{SUPOR QUE ESTAMOS NA ERA DAS MIGRAÇÕES}

O terceiro equívoco apresentado por Grimson (2011) diz respeito ao sentimento de cronocentrismo nos estudos migratórios e nas atribuições advindas das migrações internacionais contemporâneas e seus fluxos. Em um sentido geral, diversos autores já provaram que tal paradigma é verdadeiro, tais como Hatton e Williamson (1998) na célebre obra "The age of mass migration: causes and economic impact".

Para o autor, "considerar que la multiplicación de inmigrantes del Sur al Norte implica que estamos en una época de migraciones sin parangón en la historia humana es equiparar la novedad que implica esa recepción para los europeos con una novedad que debería ser asumida por el mundo entero." (GRIMSON, 2011, p. 35).

Todavia, no caso brasileiro se verifica uma segunda era das grandes imigrações, ao passo em que a primeira ocorreu ainda no século XIX. O gráfico da Figura 3 representa a evolução da série histórica do número de imigrantes no Brasil a partir do ano 2000 para comprovar que se trata de uma mass migration apenas menor do que aquela ocorrida há dois séculos: 
Figura 3 - Série histórica do número de imigrantes no Brasil - 2000;2007-2014.

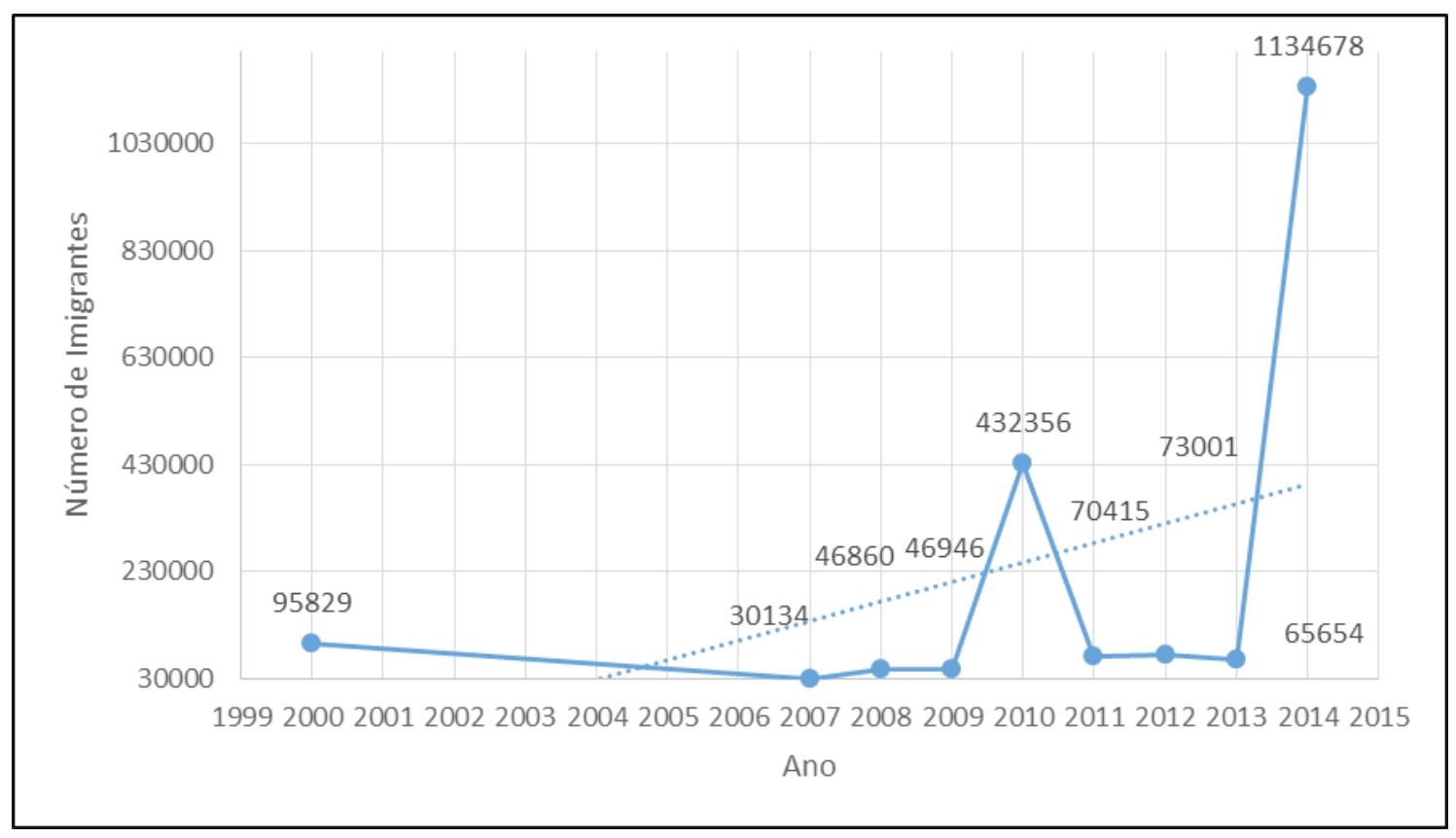

Fonte: Instituto Brasileiro de Geografia e Estatística, Departamento de Polícia Federal, Ministério do Trabalho e Emprego-Dados compilados e tabulados pelo autor

Podemos observar neste Gráfico 1, portanto, que ao invés de seguir uma linha de tendência com crescimento contínuo - linha pontilhada - o país experimentou um primeiro boom imigratório a partir de 2010 com posterior declínio e um segundo boom no biênio 2013-2014, muito acima das projeções estatísticas, o que refuta neste primeiro momento a hipótese de que o país passaria por uma "ciclicity" imigratória, ou seja, ciclos de imigração como os que ocorreram na primeira metade do século XX logo após a primeira era brasileira de imigrações em massa.

Ao entrarmos no século XXI, o cenário para o entendimento das migrações internacionais com direção ao Brasil se amplia, conforme observamos nas próprias representações cartográficas anteriores bem como as linhas de tendência destes fluxos internacionais; além do contexto nacional é preciso incorporar as transformações advindas da nova ordem internacional na divisão social do trabalho no mundo (HARVEY, 1992; SASSEN 1988).

Nesse sentido, destaca-se que o equívoco está na argumentação de Grimson (2011) e não na causa que denota como equivocada, já que se trata sim de uma nova era de migrações em massa e não localizadas estritamente no continente europeu, mas agora com um novo centro de gravidade em plena América do Sul, no Brasil.

a 


\section{SUPOR QUE "MUITA GENTE" IMPLICA “PROBLEMAS MAIORES”}

O quarto equívoco apresentado por Grimson (2011), que considera o fator de "muitos imigrantes" significarem "problemas maiores" está totalmente alinhado ao cenário brasileiro e, em especial, aquele verificado no estado do Rio Grande do Sul em relação aos imigrantes de origem caribenha e africana.

Assim como apontado por Harvey (1996), a palavra ambiente "necessariamente significa coisas diferentes para pessoas diferentes, que no seu conjunto engloba, quase literalmente, tudo que existe" (HARVEY, 1996, p. 117, tradução nossa), isto é, o ambiente imigratório no Brasil apresenta distintas nuances que vão ao encontro do equívoco apontado pelo próprio Grimson (2011).

O fato simples para se ilustrar o caráter verdadeiro deste equívoco é o cenário brasileiro: o número de imigrantes haitianos e senegaleses representa apenas 1,54\% do estoque total de imigrantes no Brasil entre 2007 e 2014, isto é, menos que trinta mil indivíduos. O número de imigrantes portugueses corresponde a $17,02 \%$ do estoque total, com mais de trezentos mil indivíduos no mesmo período.

Todavia, o destaque da mídia e os debates nos círculos sociais restringem-se àquela pequena parte de $1,54 \%$ de imigrantes, chegando-se a manchetes jornalísticas que tendem ao insólito, tais como "Florianópolis recebe mais um ônibus com 28 imigrantes" (DEOLHONAILHA, 2015) e "Mais nove haitianos desembarcam na Capital em busca de trabalho" (SANDER, 2015).

Como coloca o autor, o que ocorre no Brasil é exatamente isso: "procesos migratorios comparativamente pequeños han originados problemas graves y situaciones de exclusión y violencia social." (GRIMSON, 2011, p.36).

\section{CONFUNDIR MIGRAÇÕES COM POBREZA}

Talvez o equívoco apontado por Grimson (2011) que mais se observa à luz do cenário imigratório contemporâneo brasileiro é este, que confunde migrações com pobreza. Como coloca o autor:

“[...] las personas más pobres de cada sociedad no suelen conformar los grupos más dinámicos en la búsqueda de nuevos horizontes, por el simple motivo de que migrar es una empresa y requiere generalmente de ciertos ahorros y redes sociales. Los sectores más empobrecidos muchas veces están condenados a no poder ni siquiera migrar." (GRIMSON, 2011, p. 37).

A simples análise cartográfica das rotas dos imigrantes haitianos e senegaleses para o estado do Rio Grande do Sul, serve de exemplo para contradizer este equívoco, ao passo em que o trajeto envolve deslocamentos aéreos e terrestres de longa distância. Os mapas 
a seguir (Figuras 4 e 5) apresentam as rotas destes imigrantes em direção ao Brasil e Rio Grande do Sul, respectivamente:

Figura 4 - Rota dos imigrantes haitianos em direção ao Brasil.

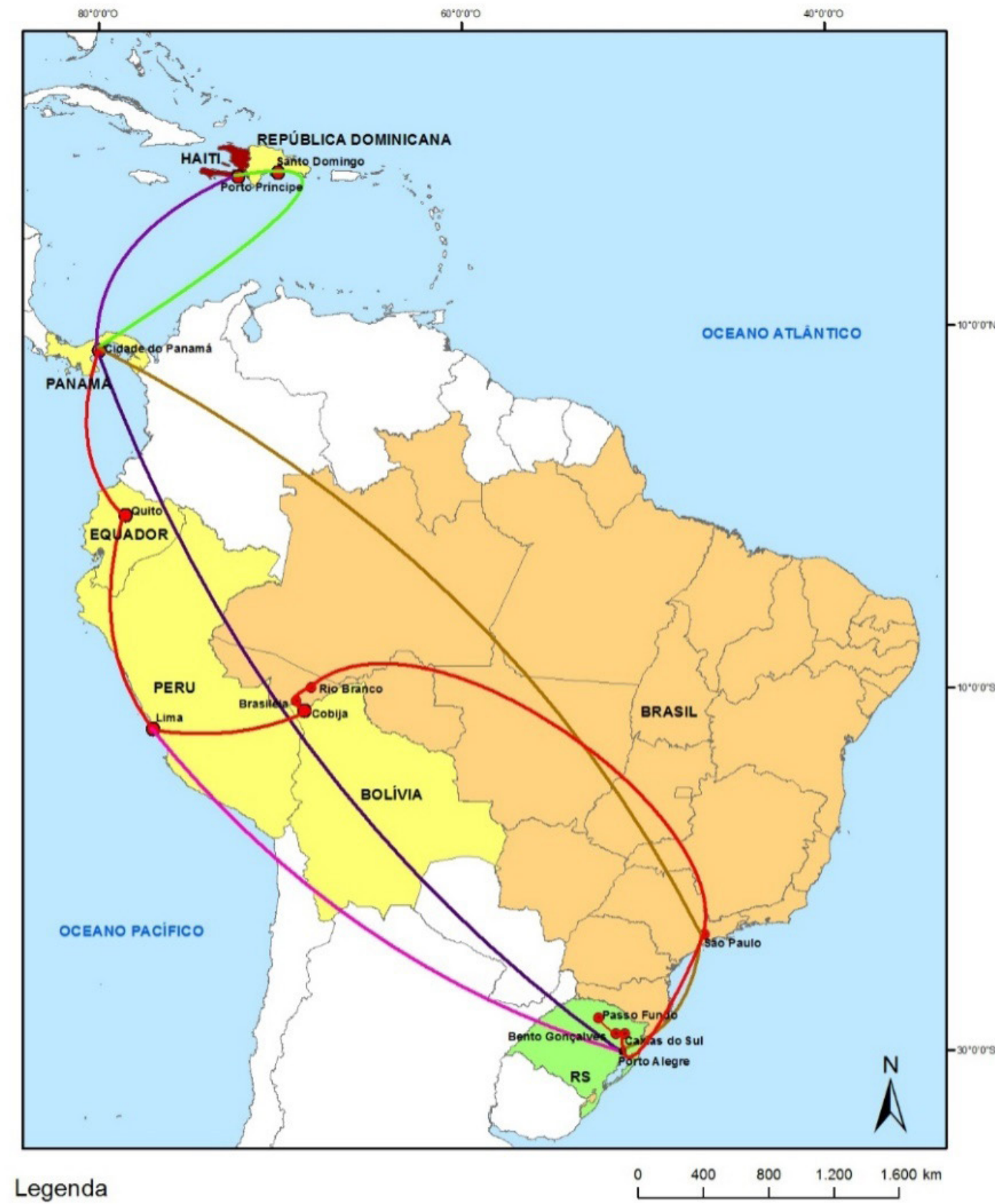

Rotas de Partida

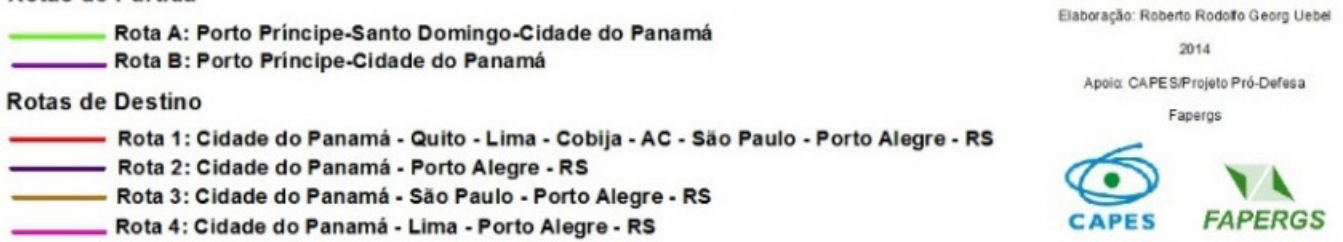

Elaborados pelo autor.

a 
Figura5 - Rota dos imigrantes senegaleses em direção ao Brasil.

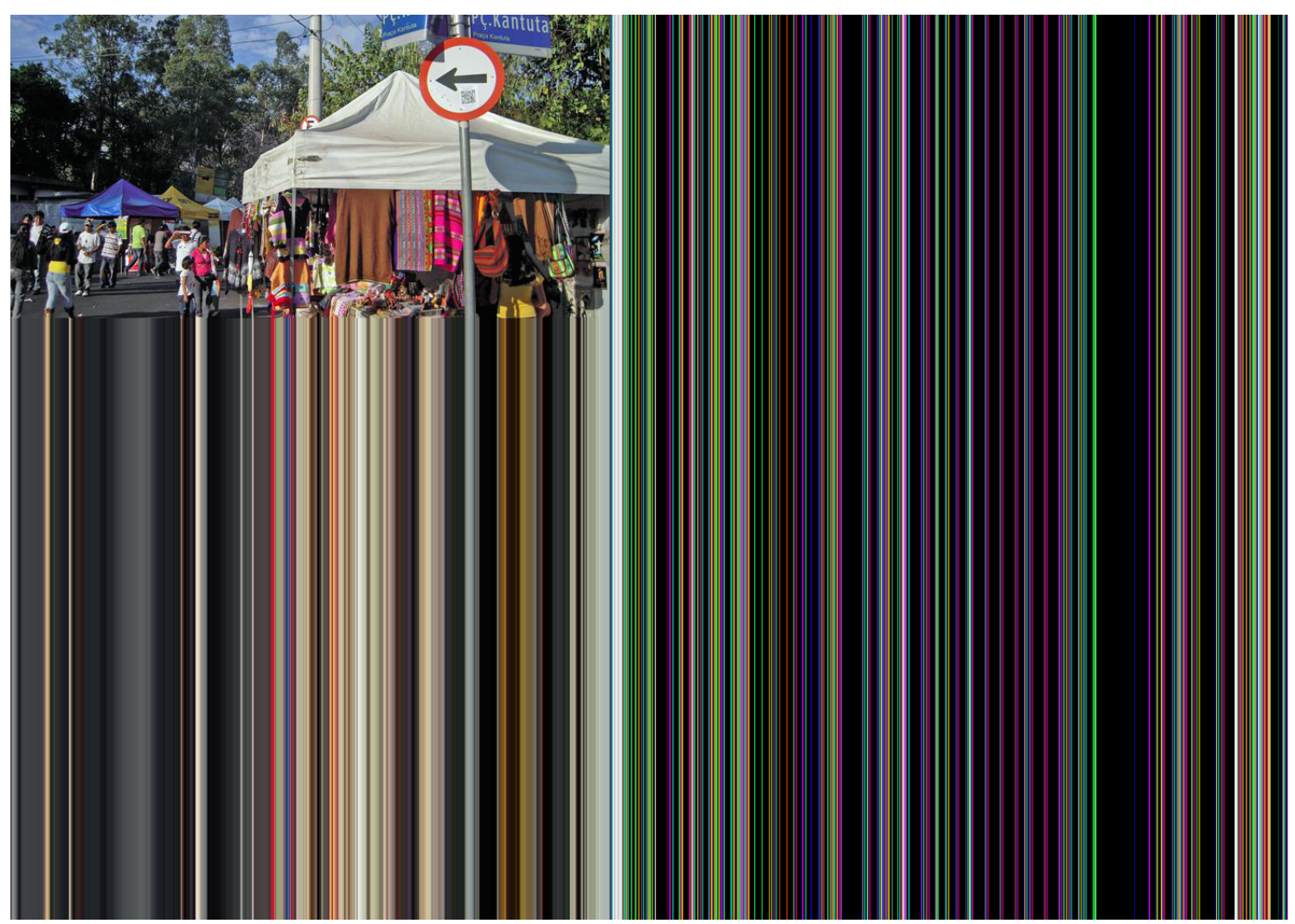

Elaborados pelo autor.

Segundo relatos recentes, tem-se que:

"Haitianos que entram no País através do Amazonas chegam a pagar US\$650, o equivalente a R \$ 1,2 mil, a 'coiotes' em troca de estadia, passagem e oportunidade de trabalho. De acordo com o delegado da Polícia Federal (PF) em Tabatinga, Alexandre Rabelo, o ‘serviço’ é acertado pelos haitianos ainda no país de origem com a ajuda de amigos e parentes. [...] a PF prendeu o suspeito, que cobrava até US $\$ 2$ mil para trazer os cidadãos haitianos do Peru até o Brasil. [...] A renda per capita anual [do Haiti] soma US\$ 410 (R\$740), o que revela o perfil social desses imigrantes, pertencentes à camada de maior poder aquisitivo. [...] Haitianos [...] contam que a ação dos 'coiotes' inicia no aeroporto de Santo Domingo, com o pagamento de US\$ 300 para a realização da viagem até Quito e segue com o desembolso de mais US\$ 200 no desembarque." (ARAÚJO, 2011, p. 1, grifo do autor).

Portanto, o caso das migrações internacionais em direção ao Brasil segue uma direção totalmente oposta ao equívoco apontado por Grimson (2011), já tanto os imigrantes não-qualificados como os que correspondem àquela parcela de mão-deobra especializada, dispõem de recursos mínimos para migrar e estabelecerem-se no país, não trazendo, portanto, pobreza ou despesas ao Estado brasileiro, ao contrário das migrações de refugiados africanos para a União Europeia, conforme a visão eurocentrista combatida pelo próprio autor. 


\section{CRER QUE AS PESSOAS “SE MOVIMENTAM COM SUAS CULTURAS"}

Este sexto equívoco apresentado por Grimson (2011) se analisado novamente pela ótica do fenômeno imigratório no Brasil contemporâneo, acaba se tornando um fato, assim como o equívoco terceiro anteriormente desconstruído e provado verdadeiro.

Se considerarmos aquilo que Wallerstein coloca no seu "Geopolitics and geoculture" (1991) sobre a cultura ser um processo criado à luz do capitalismo e suas necessidades de diferenciação e segregação, seria possível concordar com Grimson (2011) no que diz respeito a cultura não se movimentar como algo próprio do sangue do imigrante, contudo, inúmeras práticas ao redor do planeta contrapõem esta ponderaç

No caso brasileiro, duas situações comprovam que os imigrantes se movimentam com as suas culturas: os imigrantes bolivianos em São Paulo, que territorializaram a Praça da Kantuta (Figura 6), local de atividades culturais, feiras, apresentações artísticas, e uma microterritorialidade boliviana no Brasil; e o caso dos imigrantes senegaleses no Rio Grande do Sul, que já improvisam mesquitase comemoram o mês sagrado do Ramadã, mesmo dentro dos seus postos de trabalho (Figura 7).

Figura 6 - Praça da Kantuta em São Paulo.

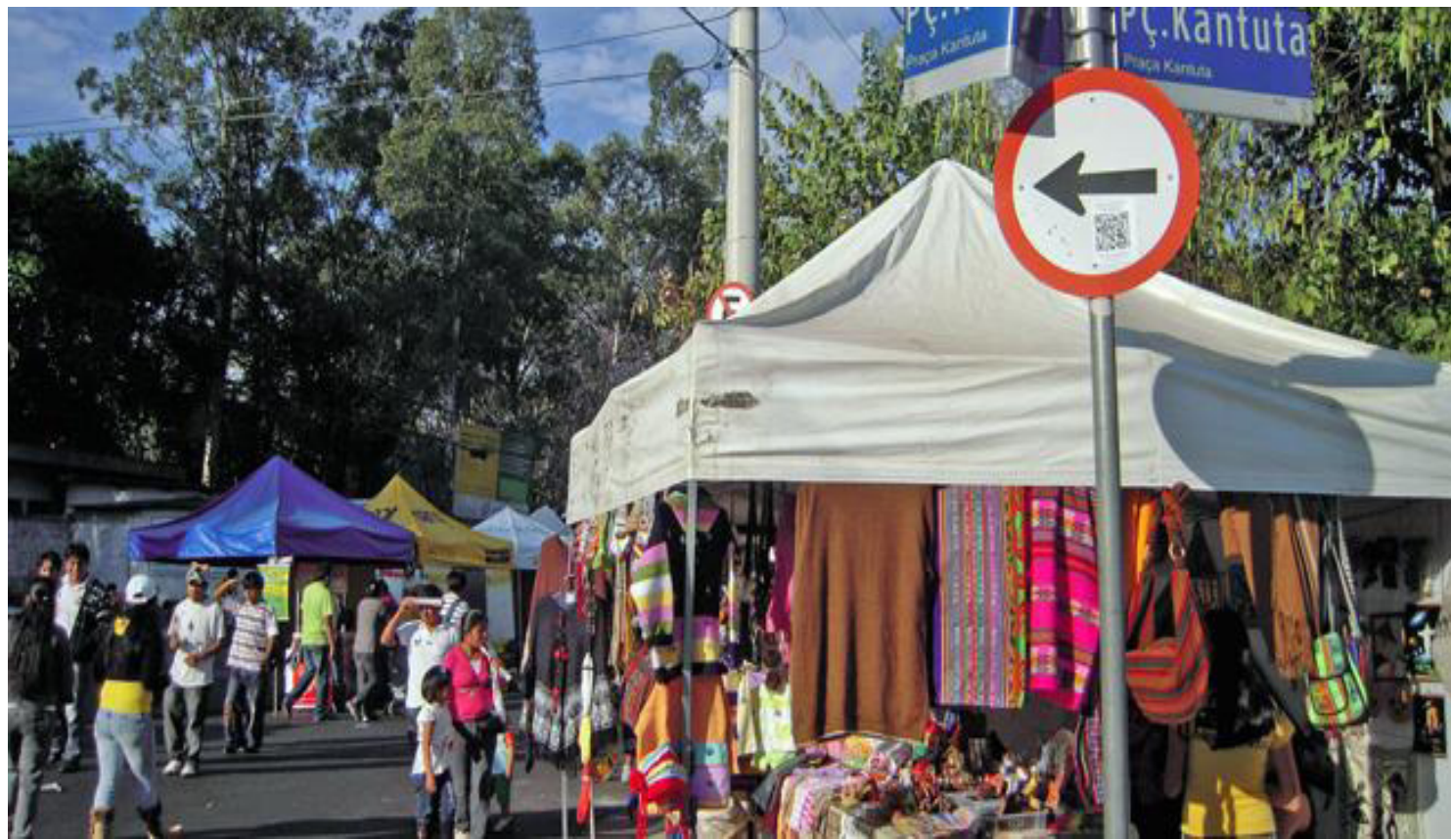

Fonte: Mario de Freitas (sitio "Radio Nederland Wereldomroep") - 14/06/2012. 
Figura 7 - Imigrante senegalês orando em fábrica de Caxias do Sul, RS.

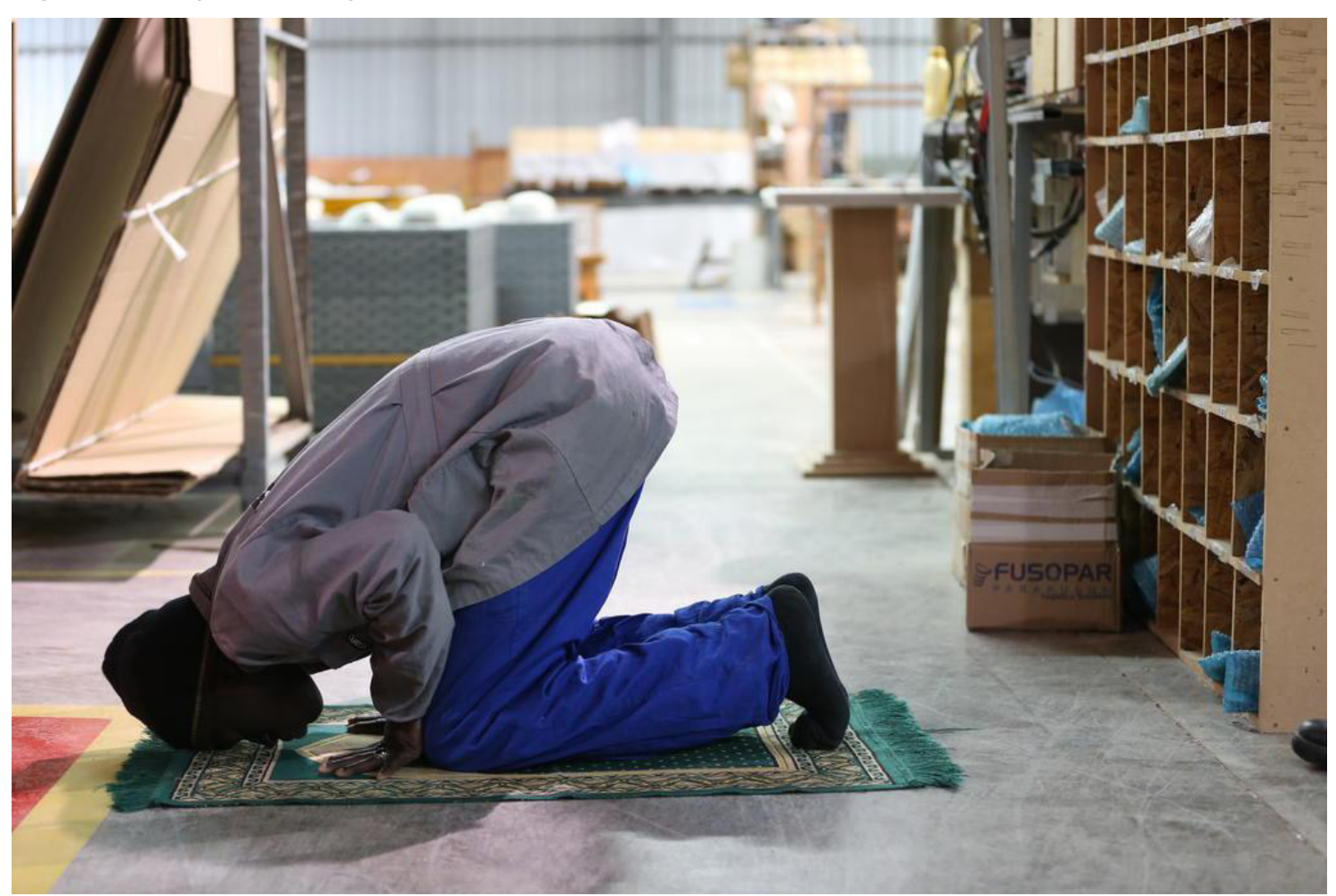

Fonte: Diego Vara (jornal "Zero Hora") - 16/08/2014.

Portanto, dentro de um aspecto geocultural e, porque não, geopolítico, a cultura move-se igualmente com a identidade do indivíduo imigrante, podendo ser integrada ou assimilada na sociedade que a recebe, conforme a literatura sempre apontara.

\section{IDENTIFICAR MIGRAÇÃO COM DIÁSPORA}

Este sétimo equívoco apresentado por Grimson (2011), que se trata de mais uma simplificação ou reducionismo, tanto midiático como acadêmico, encontra sustentação também no caso do outlook imigratório brasileiro. Não raramente, pesquisadores confundem os fluxos migratórios contemporâneos como diáspora, como no caso da recente tese de Joseph Handerson (2015) "Diáspora. As dinâmicas da mobilidade haitiana no Brasil, no Suriname e na Guiana Francesa", que equivocadamente identifica o fluxo imigratório econômico de haitianos como uma diáspora.

Por ora, como adverte Grimson, "hay migraciones sin identificación. Y la adjudicación de una identidad diaspórica a todos los migrantes implica una esencialización."(GRIMSON, 2011, p. 38). 
Logo, os distintos fluxos imigratórios para o Brasil, tanto aqueles apontados nos estudos governamentais como nas investigações acadêmicas, já supracitados, são unânimes ao colocarem que mesmo dentro de um determinado grupo, as motivações, identificações e percepções dos imigrantes são diferentes, ao contrário das diásporas clássicas, como dos armênios (MARCARIAN, 2008), por exemplo, em que há uma identificação e motivação comum. Neste sentido, mesmo os refugiados sírios ou asilados bolivianos não se enquadrariam numa caracterização de diáspora contemporânea no Brasil, confirmando o equívoco apontado por Grimson (2011), já que não há uma "essência comum”, ainda que as proveniências e destinações sejam as mesmas.

\title{
CRER QUE EXISTEM IMIGRANTES DE SEGUNDA GERAÇÃO
}

Quando Grimson apresenta que há um equívoco ao arguir-se uma segunda ou terceira geração de imigrantes, “[...] tiende a presuponer una continuidad identitaria entre padres, hijos y nietos. La identidad se portaría en la sangre. De ese modo, se postula la reproducción del estigma entre generaciones" (GRIMSON, 2011, p. 39).

Entretanto, sob uma ótica geoeconômica, por exemplo, os ciclos migratórios acabam por formar levas ou gerações de imigrantes econômicos, como no caso identificado por Uebel (2015) dos haitianos, que já possuem duas gerações de migração, a saber:

\begin{abstract}
“[...] observa-se que as quatro rotas de imigração dos haitianos são constituídas de redes de contatos e informações, distribuídas no que concluímos ser gerações de imigrantes em um curto período de tempo, isto é, a primeira geração dos imigrantes 159 haitianos, após a crise humanitária e terremoto de 2010, não tinha como destino final - ou objetivo principal - o Rio Grande do Sul e era predominantemente constituída de homens, solteiros e pais de família desacompanhados, que vislumbravam apenas a chegada ao Brasil e inserção no mercado laboral. Já a segunda geração possui um caráter distinto da primeira, ao passo em que estabelecidas as redes com os primeiros emigrados, retoma após 2013 um forte fluxo já destinado ao Rio Grande do Sul ou com a expectativa de se deslocar até um dos estados da Região Sul do Brasil, daí incluindo-se mulheres, imigrantes mais velhos, famílias completas com crianças e com graus de instrução mais variados." (UEBEL, 2015, p. 158-159).
\end{abstract}

Destarte, a motivação que levou a estas duas gerações de imigrantes, seguindo-se os preceitos de Piore (1979), é a mesma: melhores condições laborais - ou seja, salariais e possibilidade de construção de um projeto de vida familiar no Brasil, já que não havia perspectivas de retomada do crescimento do Haiti no médio e mesmo no longo prazo. $\mathrm{O}$ que as diferencia são suas caracterizações demográfico-sociais, rotas e forma como são atraídos país, além de que a segunda geração apenas emigrou por causa de uma rede já estabelecida pela primeira geração, logo, provando-se que este oitavo equívoco na verdade se trata de uma realidade quando confrontado com o cenário contemporâneo brasileiro. 


\section{CRER QUE MAIOR TEMPO DE RESIDÊNCIA IMPLICA MAIOR INTEGRAÇÃO SOCIAL}

O caso das migrações internacionais com direção ao Brasil, ainda sob uma ótica geoeconômica, mostra ser verdadeiro este equívoco apresentado por Grimson:

"No existen leyes que indiquen si habrá mayor o menor asimilación e integración. Lo que sí existe son estudios que muestran que cierto tipo de políticas públicas contribuyen a subrayar las fronteras identitarias, los estigmas y la exclusión, mientras que otras contribuyen a generar mejores condiciones para la porosidad y el diálogo intercultural." (GRIMSON, 2011, p. 40).

Tanto no caso das migrações de europeus, hipoteticamente com renda superior, como na de africanos e latino-americanos, com renda menor entre os grupos de imigrantes, observa-se no Brasil um processo de integração limitada e necessária, isto é, os imigrantes integram-se à sociedade receptora nas necessidades básicas de convívio, mas procuram manter sempre suas tradições, práxis e, inclusive, replicam em microterritorialidades.

Pode-se citar dois casos práticos como exemplo deste equívoco apresentado pelo autor: os imigrantes japoneses no Sudeste e os imigrantes senegaleses no Sul do Brasil. Ambos os grupos, de origens continentais distintas, com presença temporal diferente, procuram manter suas tradições e integrarem-se à sociedade brasileira apenas de forma limitada e necessária, especialmente no que diz respeito à esfera legal e constitucional.

No Brasil contemporâneo, ao contrário de países como o Canadá, não há uma política pública oficial de integração entre grupos migratórios, sejam estes imigrantes econômicos ou refugiados, e a sociedade brasileira, como se para o Estado os migrantes fossem naturalmente incorporados ao amálgama social e coletivo brasileiro, sendo que não há mesmo dentro da própria sociedade nacional brasileira tal coletivismo e integracionismo.

\section{A CONFUSÃO ENTRE TRANSNACIONALISMO E TRANSLOCALISMO}

Quiçá o décimo equívoco apresentado por Grimson (2011) seja aquele que mais se verifica na história das migrações internacionais para o Brasil, mais especificamente em dois períodos, que coincidem com as duas grandes eras de migração: final do século XIX e início do século XXI.

Quando o autor coloca que "una de las formas más características de esencialización es creer que todos los inmigrantes pertenecen a los grupos tal como son definidos por los Estados nacionales" (GRIMSON, 2011, p. 40-41), remetemo-nos ao exemplo dos imigrantes espanhóis, que segundo Uebel (2012), antes de identificarem-se como espanhóis, veem-se como galegos, bascos ou catalães, quando originários destas regiões. 
O mesmo ocorre, sob este diapasão do translocalismo, com a questão étnica e religiosa verificada entre os senegaleses no Rio Grande do Sul: há uma clara divisão entre aqueles que são muçulmanos e cristãos e, além disso, de suas etnias. O papel da nacionalidade cabe quase que exclusivamente ao Estado receptor nos tratos legais e migratórios, especialmente no Brasil, um país que é formado por distintos grupos e etnias sob uma égide nacional brasileira.

\section{CRER QUE TODA SITUAÇÃO MIGRATÓRIA REPRESENTA UM "ENCONTRO ENTRE DUAS CULTURAS"}

Este penúltimo equívoco discorrido por Grimson (2011) acaba por ser uma continuação do sexto equívoco, que pondera que as pessoas se movimentam com suas culturas. Contudo, há especialmente nas migrações Sul-Sul e Norte-Sul um encontro entre duas culturas.

No caso brasileiro, identifica-se claramente no caso dos refugiados sírios com os migrantes libaneses e palestinos, que apesar de migrarem por razões distintas, compartilham de espaços e práticas religiosas e culturais comuns, especialmente nas regiões transfronteiriças, como no caso das fronteiras do Brasil com o Uruguai e Paraguai, onde há uma forte presença de muçulmanos migrantes de variadas nacionalidades.

Isso não significa, entretanto, que o encontro entre as duas culturas deva se dar necessariamente entre a cultura do imigrante com a cultura do receptor, o que Grimson (2011) parece ignorar na abordagem deste possível equívoco, mas sim entre culturas migrantes num mesmo território receptor comum, como por exemplo, de latinoamericanos nos Estados Unidos, asiáticos na Austrália e Nova Zelândia, africanos no Québec, etc. Depende majoritariamente do ponto de vista e interpretação sobre qual cultura e qual encontro está-se a falar.

\section{ASSUMIR $O$ DISCURSO QUE APENAS OS NATIVOS POSSUEM DIREITOS}

Por fim, o último equívoco apresentado por Grimson (2011), talvez o mais polêmico e recorrente das discussões jurídicas, acadêmicas e coletivas acerca das migrações internacionais, tanto no Brasil como em outros países, se deve ao status legal e jurídico dos migrantes.

Apesar de parte da imprensa e sociedade considerarem que os imigrantes e refugiados são ilegais, clandestinos, proibidos, indocumentados, etc., a literatura de imigração vem propondo uma discussão e readequação destes termos vis-à-vis o cenário geopolítico internacional, em especial dos conflitos e disputas territoriais e políticas. 
É consenso neste início de século XXI que se adote o termo de "não autorizado" àqueles imigrantes e refugiados que não recebem o status requerido, autorização de trabalho ou não passem pelos trâmites migratórios e alfandegários normais ou burlem tais procedimentos, pois é garantido o livre direito de circulação universal, segundo as Cartas Magnas existentes, salvo exceções pontuais, como na Coreia do Norte, por exemplo.

Nesse sentido, embora a legislação migratória brasileira seja ainda do período ditatorial, representada pelo Estatuto do Estrangeiro (Lei No 6.815 de 19 de agosto de 1980) ela resguarda direitos importantes ao trabalho e dignidade dos imigrantes.

Em agosto de 2014 foi apresentado ao Ministério da Justiça do Brasil uma proposta de reformulação e anteprojeto de uma nova Lei das Migrações, que quando aprovada e promulgada, deixará o país com uma das legislações mais modernas do mundo no quesito de imigração, refúgio, asilo e apátridas.

As medidas propostas apontam para uma reforma no campo migratório, com a revisão administrativa no Departamento de Estrangeiros e do Comitê Nacional para os Refugiados (CONARE); a publicação de portarias que desburocratizam procedimentos; criação de mecanismos participativos junto à sociedade civil; início da estruturação de unidades de atendimento e acolhimento pelos governos locais, com convênios federais; maior inserção brasileira nos organismos e foros internacionais sobre o tema.

Ademais, a posição oficial do Governo Brasileiro em atenção especial aos imigrantes haitianos e também senegaleses segue um caráter estritamente pragmático, isto é, ligado apenas às questões de ínterim humanitário - presentes em todas as posições brasileiras na sua história diplomática - sem anseios subjetivos como uma vaga permanente no Conselho de Segurança da Organização das Nações Unidas, por exemplo, conforme segue no posicionamento oficial do Itamaraty sobre o tema:

A política migratória brasileira para nacionais do Haiti, de caráter humanitário, à luz da Resolução Normativa n. ${ }^{\circ}$ 97/20124 do Conselho Nacional de Imigração (CNIg), não guarda relação com a proposta brasileira de reforma do Conselho das Nações Unidas. Os senegaleses admitidos em território brasileiro de forma regular, ou seja, com visto, cumprem os mesmos requisitos que os demais estrangeiros dos quais se exigem, por reciprocidade, visto para admissão em território nacional. Cabe ao Ministério da Justiça, em vista de suas competências, manifestar-se sobre as ações para a acolhida de haitianos e senegaleses em território nacional. A Embaixada do Brasil em Porto Príncipe concede vistos humanitários a haitianos, à luz da Resolução Normativa n. ${ }^{0}$ 97/2012 do CNIg, prorrogada até 30 de outubro de 2015. (MINISTÉRIO DAS RELAÇÕES EXTERIORES, 2015)

Portanto, tal equívoco apresentado por Grimson (2011) não se verifica na esfera estatal e governamental no caso brasileiro, apesar de que uma pequena parcela da sociedade brasileira reivindique, por desconhecimento, xenofobia ou insipiência, uma distinção 
ou superioridade legal em relação aos imigrantes, em especial aqueles que ela considera "indesejados" ou "ameaça aos seus empregos", muito embora todas as pesquisas mostrem um direcionamento contrário, embasado em estatísticas e relatos práticos.

\section{CONCLUSÕES}

Com esta análise e correlação dos doze equívocos sobre migrações apresentados por Grimson (2011) em relação ao cenário imigratório brasileiro contemporâneo, em especial após os booms de 2010 e 2013-2014, foi possível constatar que oito equívocos são reais e existentes se analisado o contexto do Brasil: 1) Confundir migrações com migrações internacionais; 2) Confundir migrações internacionais com migrações Sul-Norte; 4) Supor que "muita gente" implica "problemas maiores"; 5) Confundir migrações com pobreza; 7) Identificar migração com diáspora; 9) Crer que maior tempo de residência implica maior integração social; 10) A confusão entre transnacionalismo e translocalismo; 12) Assumir o discurso que apenas os nativos possuem direitos. Todas estas situações se verificam na sociedade brasileira quando inquirida e arguida a contextualização imigratória recente.

Já os equívocos: 3) Supor que estamos na era das migrações; 6) Crer que as pessoas "se movimentam com suas culturas"; 8) Crer que existem imigrantes de segunda geração; 11) Crer que toda situação migratória representa um "encontro entre duas culturas"; se tornam fatos se observamos e confrontamo-nos com a realidade brasileira. Não se pode, portanto, generalizá-los e torna-los essências, já que no biênio 2013-2014, das 203 nacionalidades aferidas, apenas nove países de pequena expressão não possuíam imigrantes em território brasileiro, ou seja, um número grande demais para comportar as generalizações propostas por Grimson (2011).

O fato que se apresenta e cria um elo de ligação com as propostas do autor e a realidade brasileira é que ainda é necessária atenção do Estado e da sociedade em relação às migrações contemporâneas, seus autores, desafios e necessidades; especialmente porque coloca o Brasil na arena geopolítica dos países receptores de fluxos imigratórios. Assim como os americanos, com os mexicanos e centro-americanos; os argentinos, com os bolivianos; e os europeus, com os africanos.

Inferiu-se, portanto, que independente da origem nacional e étnica dos grupos imigratórios citados, seus objetivos, anseios e rotas levam apenas a um ponto em comum: o bem-estar social destes e seus familiares correlacionados com o desenvolvimento sociocultural e crescimento econômico dos locais que lhes receberam, empregaram e acolheram. 
As relações oriundas das imigrações contemporâneas no Brasil são, neste escopo analisado, recíprocas, positivas e enriquecedoras para ambos, imigrantes e sociedade, apesar das pontualidades negativas ainda preponderantes, tais como a xenofobia e racismo, e que devem ser combatidas, pelo bem do desenvolvimento comum e coletivo do país vis-à-vis suas ambições de inserção estratégica como um regional power e com base nos equívocos ainda existentes colocados por Grimson (2011).

O Brasil coloca-se no caminho para um processo de humanização dos fluxos das migrações internacionais que recebe anualmente, especialmente visando sua inserção geopolítica e geoeconômica no plano mundial, diferenciando-o de outros tradicionais países receptores de imigrantes e refugiados que insistem em adotar estes doze equívocos nas suas práticas e políticas.

\section{REFERÊNCIAS:}

1. BACHA, Edmar L.; KLEIN, Herbert S. Social change in Brazil: 1945-1985 The Incomplete Transition. Albuquerque: University of New Mexico Press, 1989. 346 p.

2. BARNETT, Jon; ADGER, W. Neil. Climate change, human security and violent conflict. Political Geography, [s.1.], v. 26, n. 6, p.639-655, ago. 2007. Elsevier BV. DOI: 10.1016/j.polgeo.2007.03.003. Disponível em: <http://api.elsevier.com/content/article/ PII:S096262980700039X?httpAccept=text/xml>. Acesso em: 27 jun. 2015.

3. GRIMSON, Alejandro. Doce equívocos sobre las migraciones. Nueva Sociedad, Buenos Aires, n. 233, p.34-43, maio 2011. Disponível em: <http://nuso.org/media/articles/downloads/3773_1. pdf>. Acesso em: 16 maio 2015.

4. HANDERSON, Joseph. Diáspora. As dinâmicas da mobilidade haitiana no Brasil, no Suriname e na Guiana Francesa. 2015. 429 f. Tese (Doutorado) - Curso de Antropologia Social, Universidade Federal do Rio de Janeiro, Rio de Janeiro, 2015. Disponível em: <http:// www.migrante.org.br/migrante/images/arquivos/Diaspora_Haitiana_tese_Joseph_Handerson. pdf>. Acesso em: 28 jun. 2015.

5. HARVEY, David. A condição pós-moderna: uma pesquisa sobre as origens da mudança cultural. São Paulo: Loyola, 1992. 349 p.

6. HARVEY, David. Justice, Nature, and the Geography of Difference. Oxford: Blackwell, 1996. 468 p.

7. HATTON, Timothy J.; WILLIAMSON, Jeffrey G. The age of mass migration: causes and economic impact. New York: Oxford University Press, 1998. 301 p.

8. MARCARIAN, Mônica Nalbandian. Diáspora armênia no Brasil. Revista de Estudos Orientais, São Paulo, n. 6, p.109-115, jan. 2008. Disponível em: <http://letrasorientais.fflch.usp. br/sites/letrasorientais.fflch.usp.br/files/REO_06.pdf.pdf\#page=109>. Acesso em: 28 jun. 2015. 
9. MINISTÉRIO DAS RELAÇÕES EXTERIORES. [Sistema Acesso a Informação] [09200.000102/2015-38] - Pedido Respondido. [mensagem pessoal] Mensagem recebida por: <roberto.uebel@ufrgs.br>.em: 14 abr. 2015.

10. ORGANIZAÇÃO INTERNACIONAL PARA AS MIGRAÇÕES. Perfil Migratório do Brasil 2009. Genebra: Organização Internacional para as Migrações, 2009. 148 p. Disponível em: <http://www.mte.gov.br/trab_estrang/perfil_migratorio_2009.pdf>. Acesso em: 11 nov. 2014.

11. PEREIRA, Cleidi. Porto Alegre se prepara para receber refugiados haitianos: Imigrantes serão encaminhados para o Centro Vida Humanístico, na zona norte. 2015. Disponível em: $<$ http://zh.clicrbs.com.br/rs/noticias/noticia/2015/05/porto-alegre-se-prepara-para-receberrefugiados-haitianos-4767632.html>. Acesso em: 27 jun. 2015.

12. PIORE, Michael J. Birds of passage: migrant labor and industrial societies. Nova York: Cambridge University Press, 1979. 229 p.

13. DEOLHONAILHA (Florianópolis). Florianópolis recebe mais um ônibus com 28 imigrantes. 2015. Disponível em: <http://www.deolhonailha.com.br/florianopolis/noticias/de-100-imigrantes-ja-foram-reencaminhados.html>. Acesso em: 27 jun. 2015.

14. SANDER, Isabella. Mais nove haitianos desembarcam na Capital em busca de trabalho. 2015. Disponível em: <http://jcrs.uol.com.br/site/noticia.php?codn=198212>. Acesso em: 27 jun. 2015.

15. SANTOS, Mauro Augusto dos et al. Migração: uma revisão sobre algumas das principais teorias. Belo Horizonte: UFMG/Cedeplar, 2010. 18 p. (Texto para discussão n 398). Disponível em: <http://www.cedeplar.ufmg.br/pesquisas/td/TD 398.pdf>. Acesso em: 16 set. 2014.

16. SASSEN, Saskia. The mobility of labor and capital: a study in international investment and labor flow. Nova York: Cambridge University Press, 1988. 224 p.

17. UEBEL, Roberto Rodolfo Georg. Impactos da Imigração Espanhola no Desenvolvimento Econômico e Territorial do Estado do Rio Grande do Sul no Século XX. 2012. 222 f. TCC (Graduação) - Curso de Ciências Econômicas, Departamento de Ciências Econômicas, Universidade Federal de Santa Maria, Santa Maria, 2012. Disponível em: <https://www. academia.edu/6310684/Impactos_da_Imigracao_Espanhola_no_Desenvolvimento_ Economico_e_Territorial_do_Estado_do_Rio_Grande_do_Sul_no_Seculo_XX>. Acesso em: 28 jun. 2015.

18. UEBEL, Roberto Rodolfo Georg. Análise do perfil socioespacial das migrações internacionais para o Rio Grande do Sul no início do século XXI: redes, atores e cenários da imigração haitiana e senegalesa. 2015. 248 f. Dissertação (Mestrado) - Programa de Pós-Graduação em Geografia, Universidade Federal do Rio Grande do Sul, Porto Alegre, 2015. Disponível em: $<$ http://hdl.handle.net/10183/117357>. Acesso em: 27 jun. 2015.

19. WALLERSTEIN, Immanuel. Geopolitics and geoculture: essays on the changing world-system. Cambridge: Cambridge University Press, 1991. 249 p.

Artigo recebido em 18 de janeiro de 2016.

Artigo aceito em 30 de maio de 2016. 